\section{Observations on the expression of bcg-1 gene in breast tumor and adjacent tissue}

Dear Sir,

Various clinico-pathological characteristics are evaluated for the management of breast cancer and the predictive value of these variables in determining benefit from endocrine therapy could be further refined by gene expression signatures. ${ }^{[1]} R$ ecently it has been shown that bcg-1 gene that is localized on chromosome $X$, is expressed in breast cancer specimens and not in cell lines and normal mammary epithelium. ${ }^{[2]}$ This gene shows homology with necdin, an inhibitor of cell growth and apoptosis and MAGE (melanomaassociated antigen) genes that play important role in the immune surveillance of certain tumor types. ${ }^{[3]}$ We analyzed tumor samples and normal adjacent tissues obtained from breast cancer patients for the expression of estrogen receptor- $\alpha(E R-\alpha)$ status and bcg-1 gene expression.

A total of 25 tumor samples and seven normal tissue specimens were analyzed for ER- $\alpha$ by enzyme immunoassay (Abbott Laboratories, Ilinois, USA) and were classified as ER - $\alpha$ positive or ER - $\alpha$ negative based on the cut off level of $15 \mathrm{fmol} / \mathrm{mg}$ protein. The bcg-1 gene expression in these tissue samples was studied by RT-PCR as described earlier. ${ }^{[4]}$ The oligonucleotide primers used for RT-PCR of bcg-1 gene were: 5'-AGTACCGAGAGGCGATGGA-3' (forward) and 5'-AGCCACTGAAGCCACCACT-3' (reverse) and for $\beta$-actin (internal control) were: $5^{\prime}$ TGCTATCCAGGCTGTGCTAT-3' (forward) and 5'GATGGAGTTGAAGGTAGTTT-3' (reverse). PCR
Table 1: ER- $\alpha$ and bcg-1 positivity in breast tumors and adjacent normal tissues

\begin{tabular}{cccc} 
Group & $\begin{array}{c}\text { Number } \\
\text { of cases }\end{array}$ & $\begin{array}{c}\text { ER- } \alpha \text { positive } \\
\text { cases }\end{array}$ & $\begin{array}{c}\text { bcg-1 positive } \\
\text { cases }\end{array}$ \\
\hline Adjacent normal & 7 & 4 & 7 \\
\hline Breast tumor & & & 2 \\
\hline T1 & 2 & 1 & 8 \\
\hline T2 & 8 & 4 & 1 \\
\hline T3 & 1 & 1 & 9 \\
\hline T4 & 10 & 4 & 4 \\
\hline Unclassified & 4 & 1 & 24 \\
\hline Total & 25 & 11 &
\end{tabular}

products of $297 \mathrm{bp}$ and $446 \mathrm{bp}$ were obtained respectively for bcg-1 and $\beta$-actin. ${ }^{[2,4]}$

O ur study showed that 11 tumor samples out of 25 samples were ER- $\alpha$ positive while 24 tumor samples were positive for bcg-1 expression. Four out of seven normal adjacent tissue specimens were positive for ER- $\alpha$ while all the cases expressed bcg-1 gene [Table 1].

The expression of bcg-1 gene in all the tissues irrespective of ER- $\alpha$ status indicates that its expression does not appear to be related to ER signaling and it may not have a role in breast cancer.

Kumar VL, Srivastava A ' $^{1}$ Kumar V 2 Departments of Pharmacology and 'Surgery, All India Institute of Medical Sciences, Ansari Nagar, New Delhi-110 029, ${ }^{2}$ Virology Group, International Centre for Genetic Engineering and Biotechnology, Aruna Asaf Ali Marg, New Delhi-110 067, India

Correspondence to: Dr. Vijay L. Kumar, E-mail:kumarv198@hotmail.com,

\section{References}

1. Desmedt C, Piette F, Loi S, Wang Y, Lallemand F, Haibe-Kains B, et al. Strong time dependence of the 76-gene prognostic signature for node-negative breast cancer patients in the TRANSBIG multicenter independent validation series. Clin Cancer Res 2007; 13:3207-14.

2. Kurt RA, Urba WJ, Schoof DD. Isolation of genes over expressed in freshly isolated breast cancer specimens. Breast Cancer Res Treat 2000;59:41-8.

3. Xiao J, Chen HS. Biological functions of melanoma associated antigens. World J Gastroenterol 2004; 10: 1849-53.

4. Kumar VL, Kumar S, Srivastava A, Kumar V. Observations on the presence of $E$ domain variants of estrogen receptor- $\alpha$ in the breast tumors. J Surg Oncol 2006;94:332-7. 